http://journal.nafo.int

J. Northw. Atl. Fish. Sci., Vol. 33: 1-21

\title{
Available Information for Estimating Reproductive Potential of Northwest Atlantic Groundfish Stocks
}

\author{
J. Tomkiewicz ${ }^{1}$ \\ Institute for Marine Sciences \\ Düsternbrooker Weg 20, 24105 Kiel, Germany \\ M. J. Morgan \\ Dept. of Fisheries and Oceans \\ P.O. Box 5667, St. John's, NL, Canada A1C 5X1, \\ J. Burnett \\ Northeast Fisheries Science Center \\ 166 Water Street, Woods Hole, MA 02543, USA \\ and \\ F. Saborido-Rey \\ Instituto de Investigaciones Marinas \\ Eduardo Cabello, 6, 36208 Vigo, Spain
}

\begin{abstract}
The availability of data to improve indices of stock reproductive potential was reviewed for 42 Northwest Atlantic groundfish stocks comprising gadoids, flatfishes, redfishes and grenadiers. For many of the stocks, information on population parameters such as stock size and size/age composition estimates exists for three or more decades. Data on fish age, weight, maturity and sex ratios in the population have also been extensively collected, often allowing for establishment of time series of annual data that could be used for assessing spawning stock biomass and female spawning stock. However, possibilities for estimating stock potential egg production are constrained by scarcity of fecundity data. Data on fish condition, which can be useful in developing fecundity models, were seldom collected in earlier times, but have increased in recent decades. A data richness index, combining information about data quantity and quality, ranked most gadoid stocks as "data comprehensive" with a high proportion of stocks possessing some fecundity information. Flatfish stocks generally were "data moderate" owing to slightly shorter time series of data, while redfish and grenadier stocks in general were "data restricted". Published studies linking aspects of reproductive potential with parental characteristics and/or recruitment have become more frequent as "data richness" has improved for many stocks, but generally the prevalence of such studies remains low.
\end{abstract}

Key words: biological reference points, biomass, flatfish, gadoid, grenadier, population fecundity, redfish, reproductive potential, spawning stock, stock-recruitment

\section{Introduction}

Stock-recruitment relationships imply that spawner abundance influences the recruitment potential (Myers and Barrowman, 1996). Originally, functions relating recruitment to parent stock used egg production as the index of stock reproductive potential (SRP) (Ricker, 1954; Beverton and Holt, 1957), but most studies have been based on the relationship between recruitment and spawning stock biomass (SSB). The application of total SSB as an index of egg production assumes that growth, maturation and mortality are the same for both sexes and that fecundity is proportional to body weight (Beverton and Holt, 1957). Also, the influence of spawner characteristics on reproductive features such as egg viability, fertilization success and larval survival on viable offspring production is assumed

\footnotetext{
1 Present address: Danish Institute for Fisheries Research, Kavalergaarden 6, 2920 Charlottenlund, Denmark.
} 
negligible (Ulltang, 1998; Trippel, 1999). Recent research challenging these assumptions, however, demonstrates that stock-recruitment relationships can be significantly improved by use of SRP indices that consider stock demography, spawner quality and environmental variability (Marshall et al., 1998; Scott et al., 1999; Köster et al., 2001; Murawski et al., 2001; Begg and Marteinsdottir, 2002). These studies also demonstrate that considerable amounts of data relevant to spawner-recruitment studies are available, which are not utilized in standard stock assessments (Ulltang, 1998; Trippel, 1999; Köster et al., 2003; Marshall et al., 2003).

Enhanced SRP indices have been obtained in various ways including revision of SSB, estimation of stock egg production and derivation of SRP proxies such as bioenergetic indices. Improvement of SSB estimates involves acquisition of reliable time series of data on population maturity and weight-at-age. If the proportion mature is defined as a plus group (assuming knife-edge maturity) or constant maturity ogives are used to calculate SSB, revised SSB estimates that simply account for natural variability in maturation may constitute a significant improvement (Morgan, MS 2000; Köster et al., 2003; Marshall et al., 2003). Growth, maturation and mortality are often sexually dimorphic in marine fish species with males maturing at smaller sizes and younger ages than females, and female longevity exceeding that of males (O'Brien et al., 1993; Atkinson, 1995; Trippel et al., 1997; Morgan and Colbourne, 1999). Consequently, the sex ratio in the SSB varies depending on the age/ size composition of the spawning stock, which compromises the reliability of SSB as an index of SRP (Jakobsen and Ajiad, 1999; Kraus et al., 2002). In such cases, female SSB (FSSB), based on time series of sex ratios and female maturity ogives, is a better but rarely used index of SRP.

Estimation of stock potential egg production (PEP) requires fecundity relationships as well as time series of female spawning stock size or biomass (Gundersen et al., 2000; Köster et al., 2001; Marshall et al., 2003). Fecundity varies both spatially and temporarily depending on such factors as food quantity and quality (Tyler and Dunn, 1976; Kjesbu et al., 1991; 1998; Kraus et al., 2000; Bromley et al., 2000). Most studies estimate fecundity from female body weight or length, and do not account for variations in size, quality and viability of eggs and larvae that may be influenced by female characteristics such as size/ age and condition (Hislop, 1988; Buckley et al., 1991;
Trippel, 1998; Marteinsdottir and Steinarsson, 1998; Vallin and Nissling, 2000). Egg production is generally considered the limiting factor of SRP, but differences in male sperm quantity and quality related to male attributes also may affect fertilization success and survival of progeny (Trippel and Neilson, 1992; Rakitin et al., 1999; Trippel, 2003).

The importance of various SRP parameters differs among stocks and in some cases, key variables may be applied as alternative SRP indices to improve stockrecruitment relationships (Marshall et al. 2000; Lambert et al., 2003). Bioenergetic indices represent one such alternative metric (Ware, 1980; Lambert and Dutil, 1997; Marshall et al., 1999), while in other cases, age diversity indices might be a useful generalized indicator for spawner characteristics (Marteinsdottir and Thorarinsson, 1998; Marshall et al., 2003).

In this context, historical and current information available to potentially improve SRP indices for Northwest Atlantic groundfish stocks was reviewed focusing on eight population parameters critical for estimating PEP: stock size and composition, age, weight, sex ratio, sexual maturity, fecundity and condition. An attempt was made to evaluate data quantity and quality using parameter-specific criteria and scoring systems. A "data richness index" combining quantity and quality scores indicated the utility of data in producing SRP and PEP time series considering differences between decadal time periods and among stocks representing different taxonomic groups or management bodies. An enumeration of publications on topics relevant for estimating SRP was made to summarize additional information on factors such as fertilization success, egg and larval viability and realized egg and larval production.

\section{Methods}

A set of tables was developed to tabulate available information in a standardized fashion (Morgan et al., 2003). The tables were not designed to include actual data, but to list data and studies published in journals, reports etc. or unpublished data existing in national laboratories. The first table recorded on a yearly basis presence/absence of data for each of eight parameters primary to estimating stock potential egg production: stock size, stock composition, age, sex ratio, maturity, fecundity, weight and condition. A second table indicated origin, format and reliability of the recorded data and provided additional information about, for 
example atresia, spawning time, egg and larval viability. A third table referenced previous studies of stock reproductive potential and recruitment such as egg production, critical life stages and stockrecruitment relationships. A final table listed the references of published data or contact persons for unpublished data.

In the present study, tabulated information of 42 groundfish stocks or species complexes of the Northwest Atlantic was reviewed (Table 1; Fig. 1). The stocks represented 15 different species comprising gadoids (15 stocks), flatfish (17 stocks), redfish (Sebastes fasciatus, S. mentella and S. marinus), (8 stocks or species complexes) and grenadiers (Macrourus berglax and Coryphaenoides rupestris) (2 stocks) (Table 2). All data were compiled on a species/stock basis except for four stocks of redfish, which are species complexes that are fished and managed as single units. For these units, data generally were not available at a species level and information was tabulated for species complexes, except for redfish in NAFO (Northwest Atlantic Fisheries Organization) Div. 3M, where speciesspecific survey data exist. In some instances, the records for specific stocks were tabulated by "stock experts", while others were conducted by members of the NAFO Working Group on Reproductive Potential.

Both published and unpublished data were considered as "available information", whereas unprocessed collections such as non-aged otoliths or non-computerized historic data were not, because their potential availability was uncertain. A scoring system was established, which considered both data quantity and quality. The time range was divided into 5 intervals: years before 1961, 1961-70, 1971-80, 1981-90 and 1991-2000. Each of the eight PEP parameters was evaluated separately by assigning a value of 1 to each year having data. The quantity score for each parameter in each time interval was obtained as the sum of the yearly values divided by 10 giving a maximum score of 1.0 per decade, but a potentially higher score for the pre-1961 period if data prior to 1951 were available. For data quality, scoring was performed across the same time intervals by ranking the same parameter records according to the following scheme: 3 - high quality, 2 -intermediate quality and 1 - low quality of data. Values of 2.5, 1.5 and 0.5 were used for time blocks in which data quality was mixed. The interval score for each parameter was derived by dividing the rank values for each time interval by 3 , thus constraining the maximum score to 1 for each decade. Data quality was evaluated using the following criteria: "high quality" data constitute absolute estimates based on empirical data with proper sample sizes, sampling times, and methodology; "intermediate quality" data refer to data with some, but not serious limitations in stock coverage, sample size, or methodology, or proxies of the parameter or estimates derived from analytical models; and "low quality" data consists of assigned data or indices of limited utility due to partial coverage of the stock, limited sampling size, or inadequate methodology. Specific criteria of each of the eight PEP parameters are listed in Appendix 1. An index of data richness (ranging from 0 to 1 ) was calculated for each parameter by multiplying the quantity score with the quality score in each of the four decades from 1961 to 2000. Data richness indices as well as quantity and quality scores were averaged over the 8 parameters and 4 decades to give the overall average data quantity, quality and richness for each stock.

The availability of additional information relevant for SRP estimation was determined by enumerating publications addressing the topics: spawning time, egg and larval viability, potential or realized egg production, viable egg and larval production, critical life stages, environmental influences on stock reproductive potential, and stockrecruitment relationships (Appendix 2). Publications included research documents (e.g., NAFO and International Council for the Exploration of the Sea (ICES) papers and Working Group reports) as well as papers published in peer reviewed journals. A publication was counted more than once if it addressed more than one topic. Each topic was scored for each of the time intervals, i.e. before 1961, 1961-70, 197180, 1981-90, 1991-2000, 2001-2002 (first quarter). The total number of publications per stock was calculated by summing scores over topics and time intervals.

\section{Results}

Information about stock size, stock composition, age, sex ratio, maturity and weight generally was available for most decades, while data on condition and especially fecundity data were rare for the 42 Northwest Atlantic stocks examined (Table 3). The majority of stocks had stock size, stock composition and age data for 5 years or more within 3 to 4 decades. For age, sex ratio, maturity and weight, 2 to 3 decades with 5 or more years of information were common with often a few years of data available for an 
TABLE 1. Species and stocks included in the present study according to area and management body.

\begin{tabular}{|c|c|c|c|}
\hline Common name ${ }^{1}$ & Stock name & NAFO area & Management body \\
\hline Cod & $\begin{array}{l}\text { Labrador and Northeast Newfoundland } \\
\text { Flemish Cap } \\
\text { Southern Grand Bank } \\
\text { Northern Gulf of St. Lawrence } \\
\text { Newfoundland South Coast } \\
\text { Southern Gulf of St. Lawrence } \\
\text { Eastern Scotian Shelf } \\
\text { Bay of Fundy/Western Scotian Shelf } \\
\text { Gulf of Maine } \\
\text { Georges Bank }\end{array}$ & $\begin{array}{l}2 \mathrm{~J}+3 \mathrm{KL} \\
3 \mathrm{M} \\
3 \mathrm{NO} \\
3 \mathrm{Pn} 4 \mathrm{RS} \\
3 \mathrm{Ps} \\
4 \mathrm{TVn}(\mathrm{J}-\mathrm{A}) \\
4 \mathrm{VsW} \\
4 \mathrm{X} \\
5 \mathrm{Y} \\
5 \mathrm{Z}+6\end{array}$ & $\begin{array}{l}\text { Canada (NAFO) } \\
\text { NAFO } \\
\text { NAFO } \\
\text { Canada } \\
\text { Canada } \\
\text { Canada } \\
\text { Canada } \\
\text { Canada } \\
\text { USA } \\
\text { Canada/USA }\end{array}$ \\
\hline Haddock & $\begin{array}{l}\text { Eastern Scotian Shelf } \\
\text { Bay of Fundy/Western Scotian Shelf } \\
\text { Georges Bank }\end{array}$ & $\begin{array}{l}4 \mathrm{TVW} \\
4 \mathrm{X} \\
5 \mathrm{Z}+6\end{array}$ & $\begin{array}{l}\text { Canada } \\
\text { Canada } \\
\text { Canada/USA }\end{array}$ \\
\hline Pollock & Scotian Shelf/Bay of Fundy/Georges Bank & 4VWX5Zc & Canada/USA \\
\hline White hake & Gulf of Maine-Georges Bank & $5+6$ & USA \\
\hline American plaice & $\begin{array}{l}\text { Labrador and Northeast Newfoundland } \\
\text { Grand Bank } \\
\text { Flemish Cap } \\
\text { Newfoundland South Coast } \\
\text { Gulf of Maine/Georges Bank }\end{array}$ & $\begin{array}{l}2+3 \mathrm{~K} \\
3 \mathrm{LNO} \\
3 \mathrm{M} \\
3 \mathrm{Ps} \\
5+6\end{array}$ & $\begin{array}{l}\text { Canada } \\
\text { NAFO } \\
\text { NAFO } \\
\text { Canada } \\
\text { USA }\end{array}$ \\
\hline Greenland halibut & Labrador-Eastern Newfoundland & $2+3 \mathrm{KLMNO}$ & NAFO \\
\hline Summer flounder & Mid Atlantic-Georges Bank & $5+6$ & USA \\
\hline Winter flounder & $\begin{array}{l}\text { Coastal-southern New England/Mid-Atlantic } \\
\text { Georges Bank }\end{array}$ & $\begin{array}{l}5+6 \\
5 Z h j m n\end{array}$ & $\begin{array}{l}\text { USA } \\
\text { USA }\end{array}$ \\
\hline Witch flounder & $\begin{array}{l}\text { Labrador and Northeast Newfoundland } \\
\text { Southern Grand Bank } \\
\text { Newfoundland South Coast } \\
\text { Gulf of Maine/Georges Bank }\end{array}$ & $\begin{array}{l}2 \mathrm{~J} 3 \mathrm{KL} \\
3 \mathrm{NO} \\
3 \mathrm{Ps} \\
5+6\end{array}$ & $\begin{array}{l}\text { NAFO } \\
\text { NAFO } \\
\text { Canada } \\
\text { USA }\end{array}$ \\
\hline Yellowtail flounder & $\begin{array}{l}\text { Grand Bank } \\
\text { Georges Bank } \\
\text { Southern New England } \\
\text { Cape Cod }\end{array}$ & $\begin{array}{l}3 \mathrm{LNO} \\
5 \mathrm{Ze} \\
5 \mathrm{Zw} \\
\text { US } 514-521\end{array}$ & $\begin{array}{l}\text { NAFO } \\
\text { Canada/USA } \\
\text { USA } \\
\text { USA }\end{array}$ \\
\hline Acadian redfish & $\begin{array}{l}\text { Flemish Cap } \\
\text { Gulf of Maine/Georges Bank }\end{array}$ & $\begin{array}{l}3 \mathrm{M} \\
5\end{array}$ & $\begin{array}{l}\text { NAFO } \\
\text { USA }\end{array}$ \\
\hline Deepwater redfish & Flemish Cap & $3 \mathrm{M}$ & NAFO \\
\hline Golden redfish & Flemish Cap & $3 \mathrm{M}$ & NAFO \\
\hline Redfish sp. & $\begin{array}{l}\text { Labrador-Northeast Newfoundland } \\
\text { Eastern Grand Bank } \\
\text { Southwestern Grand Bank } \\
\text { Unit } 2\end{array}$ & $\begin{array}{l}2+3 \mathrm{~K} \\
3 \mathrm{LN} \\
3 \mathrm{O} \\
3 \mathrm{Ps} 4 \mathrm{VsW}-3 \mathrm{Pn} 4 \mathrm{Vn}(\mathrm{J}-\mathrm{D})\end{array}$ & $\begin{array}{l}\text { Canada } \\
\text { NAFO } \\
\text { Canada } \\
\text { Canada }\end{array}$ \\
\hline $\begin{array}{l}\text { Roughhead grenadier } \\
\text { Roundnose grenadier }\end{array}$ & $\begin{array}{l}\text { Labrador-Eastern Newfoundland } \\
\text { Labrador-Eastern Newfoudland }\end{array}$ & $\begin{array}{l}2+3 \\
2+3\end{array}$ & $\begin{array}{l}\text { NAFO } \\
\text { NAFO }\end{array}$ \\
\hline
\end{tabular}

${ }^{1}$ Scientific names are provided in Table 2 


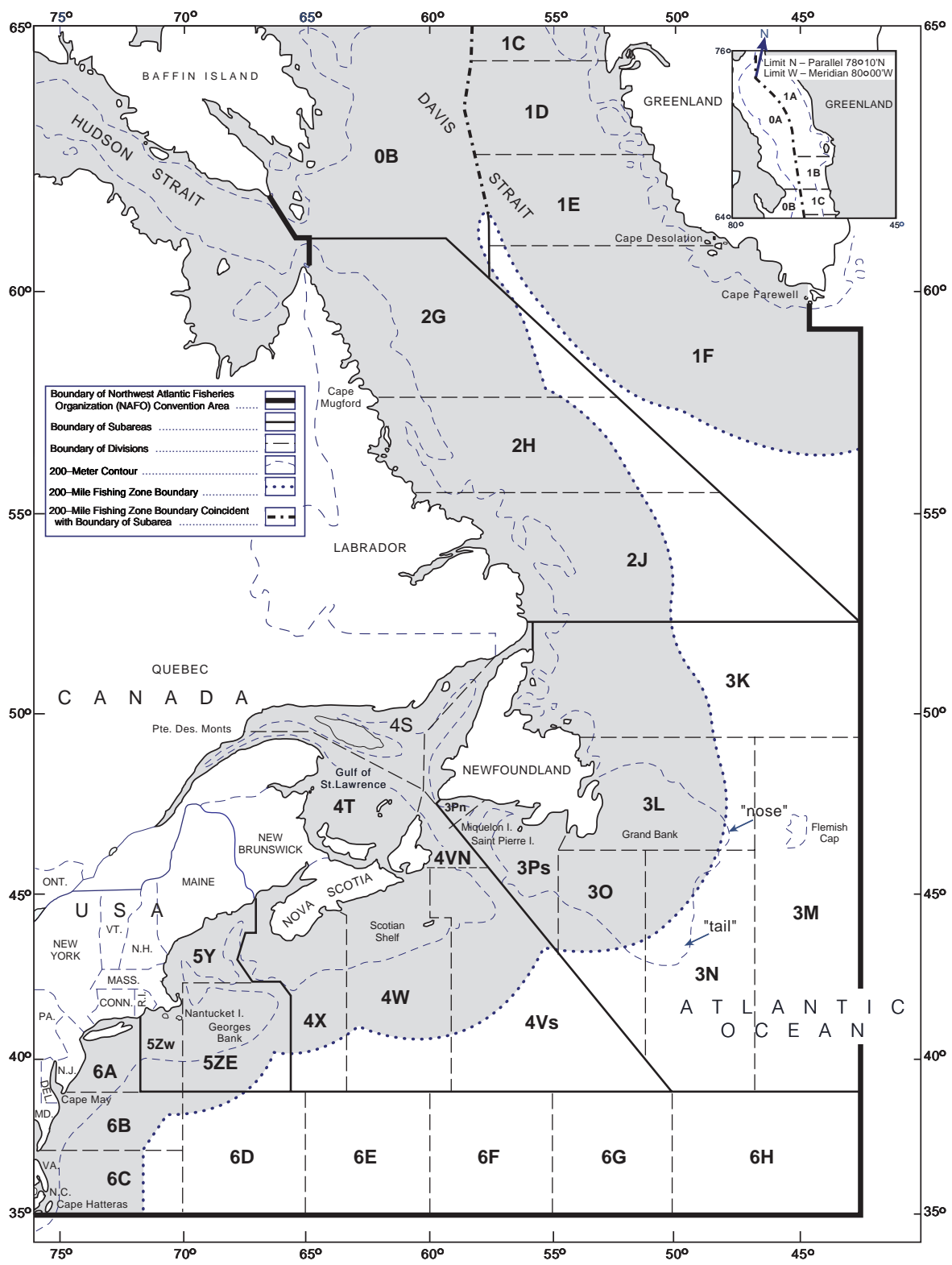

Fig. 1. NAFO convention area showing scientific and statistical subareas, divisions and subdivisions of the Northwest Atlantic.

additional decade. The availability of condition data generally was low and fecundity data were lacking for more than half of the stocks and only 1 stock, Greenland halibut (Reinhardtius hippoglossoides), had data for 5 or more years within a decade.

Data for seven of these PEP parameters increased with time reaching the highest average quantity scores in the 1991-2000 decade, while fecundity quantity scores were low throughout the time span (Fig. 2). The quality of data for all parameters generally was high in all decades with little difference in average score between the earliest and latest time intervals. Stock size time series ranged from 7 to 70 years with the variation in range being reflected in a higher standard error of the average quantity score in the early part of the period. The relatively high quality scores reflect that estimates generally are available from analytical assessments, while existence of relative abundance estimates exclusively for some stocks caused increased variability in the earliest time interval. Information on stock composition typically 
TABLE 2. Scientific names of species included in the present study.

\begin{tabular}{|c|c|c|}
\hline Species group & Common name & Order, family and species \\
\hline \multirow[t]{5}{*}{ Gadoids } & & Gadiformes, Gadidae: \\
\hline & Cod & Gadus morhua (Linneaus) \\
\hline & Haddock & Melanogrammus aeglefinus (Linneaus) \\
\hline & Pollock & Pollachius virens (Linneaus) \\
\hline & White hake & Urophycis tenuis (Mitchill) \\
\hline \multirow[t]{8}{*}{ Flatfishes } & & Pleuronectiformes, Pleuronectidae: \\
\hline & American plaice & Hippoglossoides platessoides (Fabricius) \\
\hline & Greenland halibut & Reinhardtius hippoglossoides (Walbaum) \\
\hline & Winter flounder & Pseudopleuronectes americanus (Walbaum) \\
\hline & Witch flounder & Glyptocephalus cynoglossus (Linneaus) \\
\hline & Yellowtail flounder & Limanda ferruginea (Storer) \\
\hline & & Pleuronectiformes, Bothidae: \\
\hline & Summer flounder & Paralichthys dentatus (Linneaus) \\
\hline \multirow[t]{5}{*}{ Redfishes } & & Scorpaeniformes, Scorpaenidae: \\
\hline & Acadian Redfish & Sebastes fasciatus (Storer) \\
\hline & Deepwater Redfish & Sebastes mentella (Travin) \\
\hline & Golden Redfish & Sebastes marinus (Linneaus) \\
\hline & Redfish spp. & S. fasciatus, mentella, or marinus \\
\hline \multirow[t]{3}{*}{ Grenadiers } & & Gadiformes, Macrouridae: \\
\hline & Roughhead grenadier & Macrourus berglax (Lacépède) \\
\hline & Roundnose grenadier & Coryphaenoides rupestris (Gunnerus) \\
\hline
\end{tabular}

accompanies stock size estimates both with respect to amount and origin, which is reflected in similar average quantity and quality scores for the time range. Data on fish age, sex ratios, maturity and weight for most stocks did not extend back to the beginning of the time series on stock size and stock composition, and data on condition mainly have become available in the most recent decade. The average quality scores for maturity, fecundity and condition data are lower than for stock composition, age, sex ratio, and weight for the last decade. The lower quality of these parameters is due in part to the methods used to collect these data (Appendix 1). For maturity data, histological or other verification of macroscopic maturity scales or staging is needed to ascertain data quality for many stocks. For fecundity, both the methods used and the number of samples influence the quality of the data. The increase in quality of condition data in recent decades is related to intensified sampling. Any additional gains in the quality of condition data will require new approaches such as measurements of liver lipid content or liver weight to estimate energetic or hepatosomatic condition indices.
Data richness indices integrating the information on data quantity and quality reflected the potential to produce reliable time series for the PEP parameters (Fig. 3). As would be expected, fecundity and condition had the lowest average data richness scores among parameters indicating that time series rarely can be established, though the condition score improved during 1991-2000. For the remaining parameters, the average data richness scores for the period indicated that data series comprising at least 2 to 3 decades exist for the majority of stocks examined. On a stock basis, the average data richness indices ranged from a minimum of 0.10 to a maximum of 0.80 (Table 4 ). Within this range, $26 \%$ of the stocks were "data comprehensive" with average data richness indices above 0.66 (i.e. $2 / 3$ of the maximum value), $52 \%$ were "data moderate" with indices between 0.33 and 0.66 , while $22 \%$ of the stocks were "data restricted" with average data richness indices below 0.33. The lower average data richness indices between "data moderate" stocks compared with "data comprehensive" were related to lower data availability in the early decades, while "data restricted" stocks additionally tended to have poorer data quality. The 

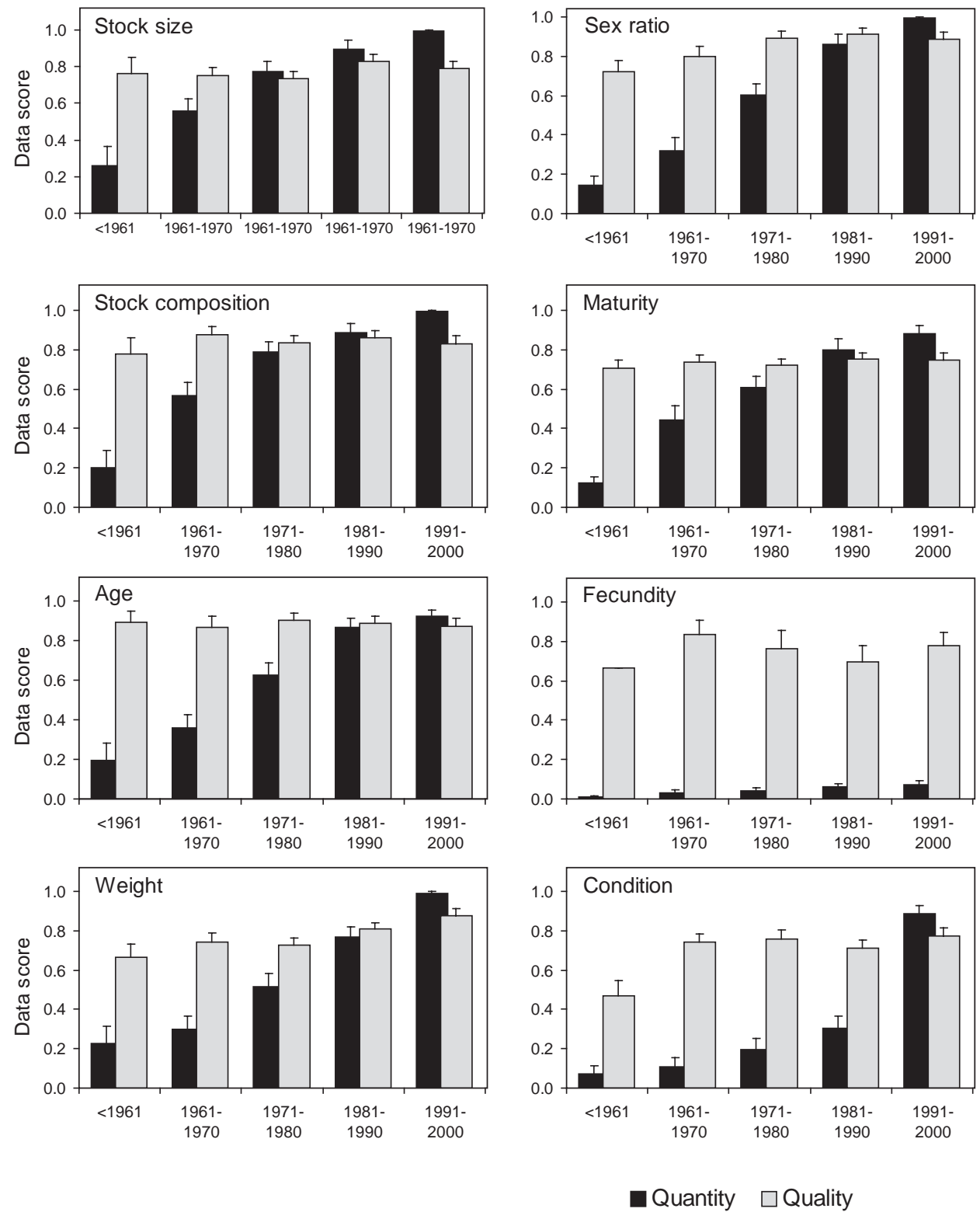

Fig. 2. Average score of stocks in quantity and quality of data on eight primary parameters related to stock reproductive potential. Maximum score for a decade is 1 . For methods of scoring, see text and Appendix 1. The standard error of each average score is shown.

probability of stocks having fecundity data increased with level of data richness. The percentage of stocks with fecundity information was highest for "data comprehensive" stocks (82\%), intermediate for "data moderate" stocks $(41 \%)$ and lowest for "data restricted" stocks (11\%). Also, the number of years with fecundity data differed among these groups. 'Data comprehensive' stocks had on average 4.7 years of data, 'data moderate' stocks on average 1.7 years, while 'data limited' stocks had fecundity data for only
0.2 years on average. The pattern observed for condition data differed with on average 7.6, 2.6 and 2.6 years of data within these respective groups.

The average quality and quantity scores were not closely related per se, but tended to differ between taxonomic groups (Fig. 4). The average quantity scores generally were higher for gadoids and flatfishes than for the grenadiers and redfish, but with substantial variability in the latter. Also the average 
TABLE 3. Number of stocks with data available for different numbers of years and decades based on data quantity scores $(\mathrm{n}=42)$.

\begin{tabular}{|c|c|c|c|c|c|c|c|c|c|}
\hline \multirow[b]{2}{*}{ Primary parameter } & \multicolumn{4}{|c|}{$\begin{array}{l}\text { No. of Stocks with Minumum } \\
5 \text { Years of Data Within }\end{array}$} & \multicolumn{4}{|c|}{$\begin{array}{l}\text { No. of Stocks with Minimum } \\
1-4 \text { years of Data Within }\end{array}$} & \multirow[t]{2}{*}{ No Data } \\
\hline & 1 decade & 2 decades & 3 decades & 4 decades & 1 decade & 2 decades & 3 decades & 4 decades & \\
\hline Stock size & 42 & 38 & 33 & 26 & 42 & 39 & 38 & 27 & - \\
\hline Stock composition & 42 & 37 & 34 & 26 & 42 & 39 & 37 & 28 & - \\
\hline Age & 42 & 35 & 27 & 14 & 42 & 39 & 34 & 19 & - \\
\hline Sex ratio & 42 & 40 & 26 & 11 & 42 & 40 & 40 & 18 & - \\
\hline Maturity & 40 & 37 & 25 & 15 & 42 & 39 & 38 & 20 & - \\
\hline Fecundity & 1 & 1 & 0 & 0 & 19 & 12 & 6 & 2 & 23 \\
\hline Weight & 42 & 33 & 22 & 12 & 42 & 39 & 28 & 15 & - \\
\hline Condition & 41 & 11 & 8 & 3 & 41 & 27 & 11 & 8 & 1 \\
\hline
\end{tabular}

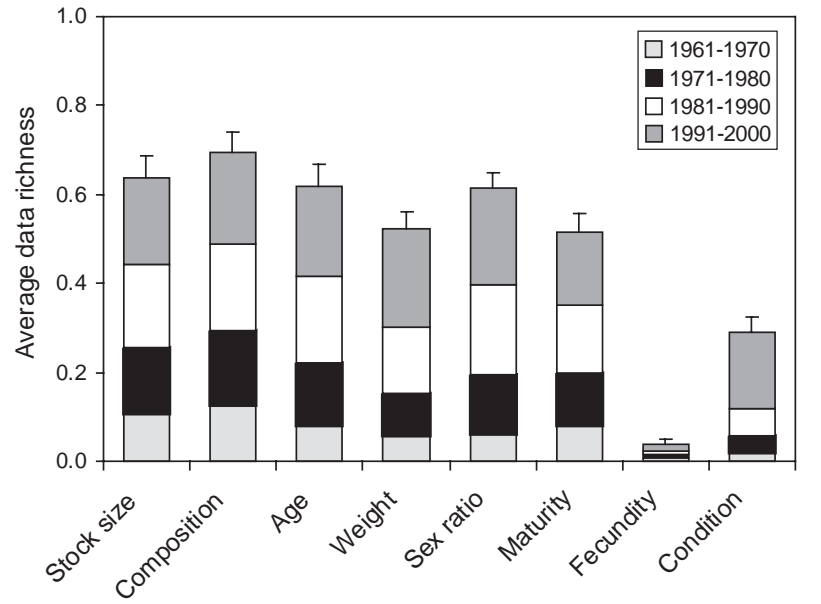

Fig. 3. Average data richness indices of the reviewed stocks for the period 1961-2000 for the eight primary parameters related to reproductive potential. For each parameter, standard error and relative contribution of different decades to the average are shown.

quality scores were high for gadoids and flatfish stocks, while data quality was lower for grenadiers and redfish stocks whose distribution in deep waters makes adequate survey coverage difficult. Furthermore for redfish, the lack of species separation has constrained the quality of data.

The overall average data richness indices showed that differences among various species groups occurred in the early part of the period (Fig. 5). Gadoid stocks frequently possessed data of good quality even in the early decades, when data availability of the other species groups was low (Table 4). In the two most recent decades, the data richness of flatfish stocks has markedly improved reaching the general level of gadoid data richness. The data richness of redfish and grenadiers has improved over time, but most stocks have still not reached the level of gadoids and flatfishes mainly due to low data quality. Accordingly, the average data richness generally increased over the past four decades for all management bodies (Fig. 5). The average data richness of the NAFO stocks is relatively low, primarily because 6 out of the 14 NAFO stocks are low scoring redfish and grenadier stocks (Tables 1 and 4). Average data richness was relatively high for four bilaterally assessed Canada/USA stocks in all decades, these stocks being gadoids and flatfishes. The USA-managed stocks lack mainly fecundity data to reach maximum scores in the most recent decade.

Both within and across decades, considerable differences existed among the four species groups in data richness in each of the eight primary parameters (Fig. 6). The gadoid stocks exhibited the highest data richness scores in all parameters except maturity in the three earlier decades. In the most recent decade, gadoid data richness improved for weight and condition, but slightly declined for some other parameters, while the indices for flatfishes improved except for age and fecundity. For these two species groups, main areas for potential improvement comprise fecundity, maturity and condition. For the redfish and grenadiers, data richness of most parameters improved over time, but still remain at best intermediate. Fecundity data are totally absent for redfish and are scarce for the grenadier stocks. For both groups, data on maturity are required to improve indices of reproductive potential.

The availability of additional information related to reproductive potential or stock-recruitment relationships showed the same increasing trend in recent decades as data on primary parameters 
TABLE 4. Data quantity, quality and richness index of stocks for the period 1961-2000.

\begin{tabular}{|c|c|c|c|c|c|c|c|c|c|c|}
\hline \multirow{2}{*}{ Common name } & \multirow{2}{*}{ NAFO area } & \multicolumn{4}{|c|}{ Average quantity score } & \multicolumn{4}{|c|}{ Average quality score } & \multirow{2}{*}{$\begin{array}{c}\text { Average data } \\
\text { richness }\end{array}$} \\
\hline & & $\begin{array}{r}1961- \\
1970\end{array}$ & $\begin{array}{r}1971- \\
1980\end{array}$ & $\begin{array}{r}1981- \\
1990\end{array}$ & $\begin{array}{r}1991- \\
2000\end{array}$ & $\begin{array}{r}1961- \\
1970\end{array}$ & $\begin{array}{r}1971- \\
1980\end{array}$ & $\begin{array}{r}1981- \\
1990\end{array}$ & $\begin{array}{c}1991- \\
2000\end{array}$ & \\
\hline \multirow[t]{10}{*}{$\overline{C o d}$} & $2 \mathrm{~J}+3 \mathrm{KL}$ & 0.85 & 0.80 & 0.91 & 0.90 & 0.92 & 0.95 & 0.88 & 0.54 & 0.73 \\
\hline & $3 \mathrm{M}$ & 0.40 & 0.58 & 0.79 & 0.75 & 0.58 & 0.75 & 0.83 & 0.90 & 0.53 \\
\hline & $3 \mathrm{NO}$ & 0.70 & 0.74 & 0.90 & 0.90 & 0.94 & 0.93 & 0.96 & 0.92 & 0.77 \\
\hline & 3Pn4Rs & 0.00 & 0.49 & 0.83 & 0.86 & & 0.75 & 0.90 & 0.94 & 0.48 \\
\hline & 3Ps & 0.68 & 0.78 & 0.88 & 0.90 & 0.86 & 0.88 & 0.90 & 0.92 & 0.72 \\
\hline & $4 \operatorname{TVn}(\mathrm{J}-\mathrm{A})$ & 0.63 & 0.89 & 0.89 & 0.90 & 0.90 & 0.92 & 0.92 & 0.94 & 0.75 \\
\hline & $4 \mathrm{VsW}$ & 0.76 & 0.88 & 0.88 & 0.90 & 0.86 & 0.88 & 0.88 & 0.85 & 0.76 \\
\hline & $4 \mathrm{X}$ & 0.85 & 0.88 & 0.91 & 0.91 & 0.64 & 0.83 & 0.88 & 0.92 & 0.74 \\
\hline & $5 \mathrm{Y}$ & 0.24 & 0.63 & 0.74 & 0.86 & 0.90 & 0.90 & 0.94 & 0.98 & 0.58 \\
\hline & $5 Z+6$ & 0.24 & 0.66 & 0.75 & 0.89 & 0.87 & 0.89 & 0.92 & 0.96 & 0.59 \\
\hline \multirow[t]{3}{*}{ Haddock } & 4TVW & 0.76 & 0.88 & 0.88 & 0.91 & 0.93 & 0.93 & 0.93 & 0.96 & 0.80 \\
\hline & $4 X$ & 0.79 & 0.91 & 0.85 & 0.80 & 0.90 & 0.92 & 0.94 & 0.94 & 0.77 \\
\hline & $5 Z+6$ & 0.70 & 0.75 & 0.75 & 0.86 & 0.89 & 0.89 & 0.89 & 0.95 & 0.69 \\
\hline Pollock & 4VWX5Zc & 0.76 & 0.88 & 0.88 & 0.81 & 0.79 & 0.90 & 0.95 & 0.88 & 0.73 \\
\hline White hake & $5+6$ & 0.20 & 0.35 & 0.71 & 0.88 & 0.92 & 0.88 & 0.88 & 0.95 & 0.49 \\
\hline \multirow[t]{5}{*}{ American plaice } & $2+3 \mathrm{~K}$ & 0.10 & 0.30 & 0.65 & 0.88 & 1.00 & 0.87 & 0.86 & 0.86 & 0.42 \\
\hline & $3 \mathrm{LNO}$ & 0.68 & 0.70 & 0.83 & 0.88 & 0.86 & 0.94 & 0.90 & 0.98 & 0.73 \\
\hline & $3 \mathrm{M}$ & 0.00 & 0.15 & 0.50 & 0.81 & & 1.00 & 0.90 & 0.86 & 0.33 \\
\hline & $3 P s$ & 0.10 & 0.66 & 0.76 & 0.88 & 0.67 & 0.56 & 0.81 & 0.86 & 0.45 \\
\hline & $5+6$ & 0.20 & 0.38 & 0.75 & 0.86 & 0.83 & 0.86 & 0.92 & 0.95 & 0.50 \\
\hline Greenland halibut & $2+3 \mathrm{KLMNO}$ & 0.04 & 0.45 & 0.79 & 0.95 & 0.67 & 0.67 & 0.67 & 0.67 & 0.37 \\
\hline Summer flounder & $5+6$ & 0.20 & 0.44 & 0.74 & 0.86 & 0.83 & 0.87 & 0.92 & 0.95 & 0.51 \\
\hline \multirow[t]{2}{*}{ Winter flounder } & $5+6$ & 0.20 & 0.39 & 0.76 & 0.86 & 0.83 & 0.87 & 0.90 & 0.95 & 0.50 \\
\hline & 5Zhjmn & 0.20 & 0.44 & 0.74 & 0.86 & 0.83 & 0.87 & 0.92 & 0.95 & 0.51 \\
\hline \multirow[t]{4}{*}{ Witch flounder } & $2 \mathrm{~J} 3 \mathrm{KL}$ & 0.00 & 0.48 & 0.70 & 0.79 & & 0.67 & 0.86 & 0.86 & 0.40 \\
\hline & $3 \mathrm{NO}$ & 0.00 & 0.54 & 0.76 & 0.79 & & 0.81 & 0.83 & 0.88 & 0.44 \\
\hline & $3 \mathrm{Ps}$ & 0.50 & 0.54 & 0.65 & 0.80 & 0.67 & 0.89 & 0.86 & 0.86 & 0.51 \\
\hline & $5+6$ & 0.20 & 0.38 & 0.80 & 0.86 & 0.83 & 0.86 & 0.94 & 0.98 & 0.52 \\
\hline \multirow[t]{4}{*}{$\begin{array}{l}\text { Yellowtail } \\
\text { flounder }\end{array}$} & $3 \mathrm{LNO}$ & 0.34 & 0.70 & 0.78 & 0.88 & 0.61 & 0.72 & 0.77 & 0.83 & 0.51 \\
\hline & $5 \mathrm{Ze}$ & 0.30 & 0.58 & 0.75 & 0.86 & 0.89 & 0.92 & 0.92 & 0.95 & 0.58 \\
\hline & $5 Z w$ & 0.33 & 0.73 & 0.75 & 0.86 & 0.87 & 0.92 & 0.92 & 0.95 & 0.62 \\
\hline & US 514-521 & 0.20 & 0.36 & 0.70 & 0.86 & 0.83 & 0.87 & 0.92 & 0.95 & 0.49 \\
\hline \multirow[t]{2}{*}{ Acadian redfish } & $3 \mathrm{M}$ & 0.00 & 0.00 & 0.00 & 0.86 & & & & 0.81 & 0.17 \\
\hline & 5 & 0.25 & 0.60 & 0.69 & 0.85 & 1.00 & 0.94 & 0.94 & 0.95 & 0.57 \\
\hline Deepwater redfish & $3 \mathrm{M}$ & 0.00 & 0.00 & 0.00 & 0.86 & & & & 0.81 & 0.17 \\
\hline Golden redfish & $3 \mathrm{M}$ & 0.23 & 0.04 & 0.25 & 0.86 & 0.33 & 0.33 & 0.77 & 0.81 & 0.24 \\
\hline \multirow[t]{4}{*}{ Redfish sp. } & $2+3 \mathrm{~K}$ & 0.23 & 0.28 & 0.76 & 0.88 & 0.67 & 0.33 & 0.33 & 0.33 & 0.20 \\
\hline & $3 \mathrm{LN}$ & 0.30 & 0.25 & 0.31 & 0.88 & 0.50 & 0.33 & 0.33 & 0.33 & 0.16 \\
\hline & 30 & 0.23 & 0.35 & 0.61 & 0.88 & 0.67 & 0.33 & 0.33 & 0.33 & 0.19 \\
\hline & $\begin{array}{l}\text { 3Ps4VsW- } \\
\text { 3Pn4Vn (J-D) }\end{array}$ & 0.34 & 0.00 & 0.00 & 0.58 & 0.67 & & & 0.33 & 0.10 \\
\hline $\begin{array}{l}\text { Roughhead } \\
\text { grenadier }\end{array}$ & $2+3$ & 0.10 & 0.60 & 0.41 & 0.61 & 0.33 & 0.39 & 0.57 & 0.57 & 0.19 \\
\hline $\begin{array}{l}\text { Roundnose } \\
\text { grenadier }\end{array}$ & $2+3$ & 0.31 & 0.45 & 0.60 & 0.54 & 0.33 & 0.33 & 0.33 & 0.33 & 0.16 \\
\hline
\end{tabular}

(Table 5). Publications related to spawning time have been the most numerous, even in the early decades. Many of the spawning time studies are analyses of egg abundance from ichthyoplankton surveys, which have regularly been conducted for some stocks and provide useful knowledge about timing and location 


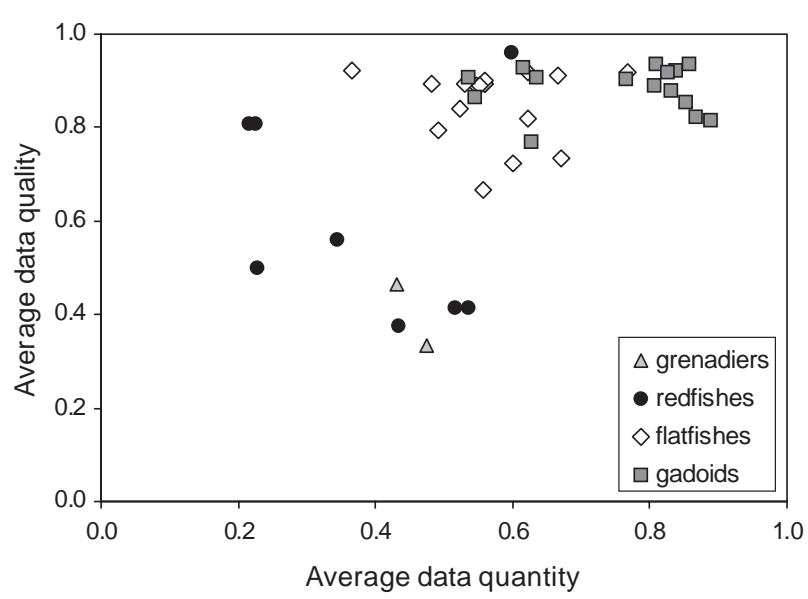

Fig. 4. Average quality score of available data in relation to average quantity score of stocks according to species group $(n=42)$.
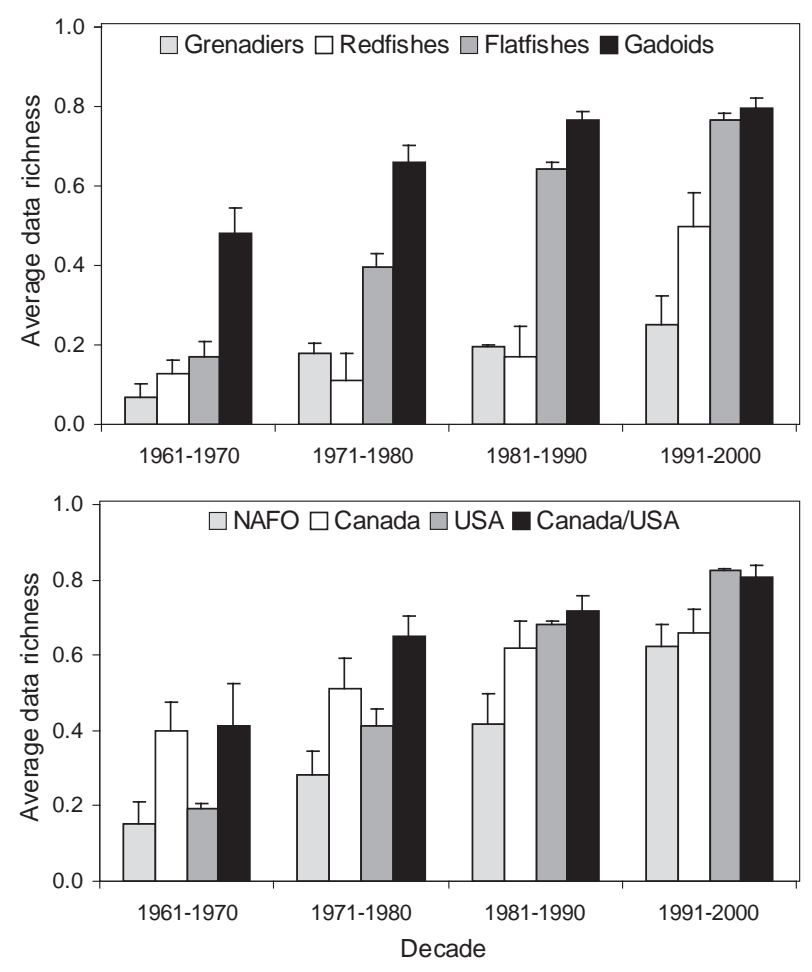

Fig. 5. Average data richness according to species group and management body, respectively, in different decades. Standard error of each average is shown.

of spawning. Similarly, the main source of data on potential/realized egg production and viable egg/larval production has been ichthyoplankton surveys, but publications on these topics have been less frequent.
Information about egg and larval viability originates mainly from experimental work and publications in this area have mainly appeared in recent decades. No published studies on critical life stages in the recruitment process were recorded, although a few papers on stock-recruitment relationships and environmental influences on SRP were published in the 1990s. The number of publications related to these topics was to some extent linked to the average data richness of the stocks and consequently differed among species groups (Fig. 7). The highest number of publications was for gadoid stocks and flatfishes with few published studies on redfish and grenadiers.

\section{Discussion}

In the 1950 s when stock-recruitment theories were developed, empirical data to test underlying relationships were scarce (Ricker, 1954; Beverton and Holt, 1957). Information about growth and reproduction existed largely from single studies of fish biology and data constraints typically necessitated simplification of SRP indices to establish stockrecruitment curves. In subsequent decades, concurrent with improvements of assessment theory and methods, more systematic sampling of data for many traditional fish stocks was conducted. National research surveys and catch monitoring programs were increased after implementation of catch regulations for the declining groundfish stocks in the 1970 s and extension of jurisdiction to 200 miles in 1977, in order to better control fisheries activities and reflect the extended fishing zone (Pinhorn and Halliday, 1990; Rivard and Maguire, 1993). International collaboration through the Standing Committee on Research and Statistics of the International Commission for the Northwest Atlantic (ICNAF) as well as national groundfish management programs further strengthened catch sampling plans and studies of population biology were augmented by research programs to base management programs on sound scientific information. Canadian and USA survey monitoring programs have gradually been extended to improve stock and area coverage, but also foreign countries with fleets fishing in the Northwest Atlantic have conducted surveys and scientific studies on specific stocks. Consequently, data intensity progressively increased over the decades and considerable amounts of data to enhance SRP indices and S-R relationships now exist, however this information is not extensively used in stock assessment and management (Trippel, 1999; Marshall et al., 2003). 


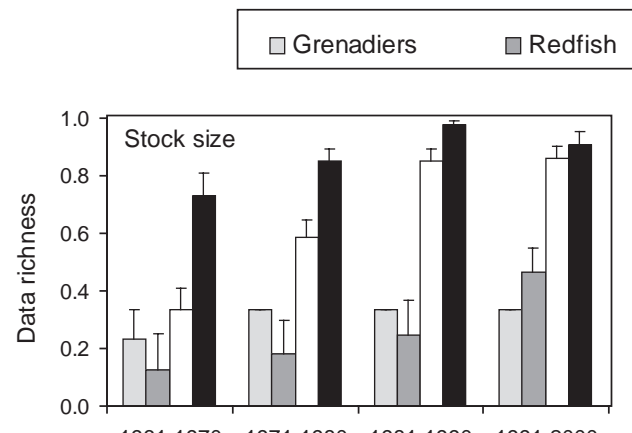

$\square$ Flatfish $\quad \square$ Gadoids
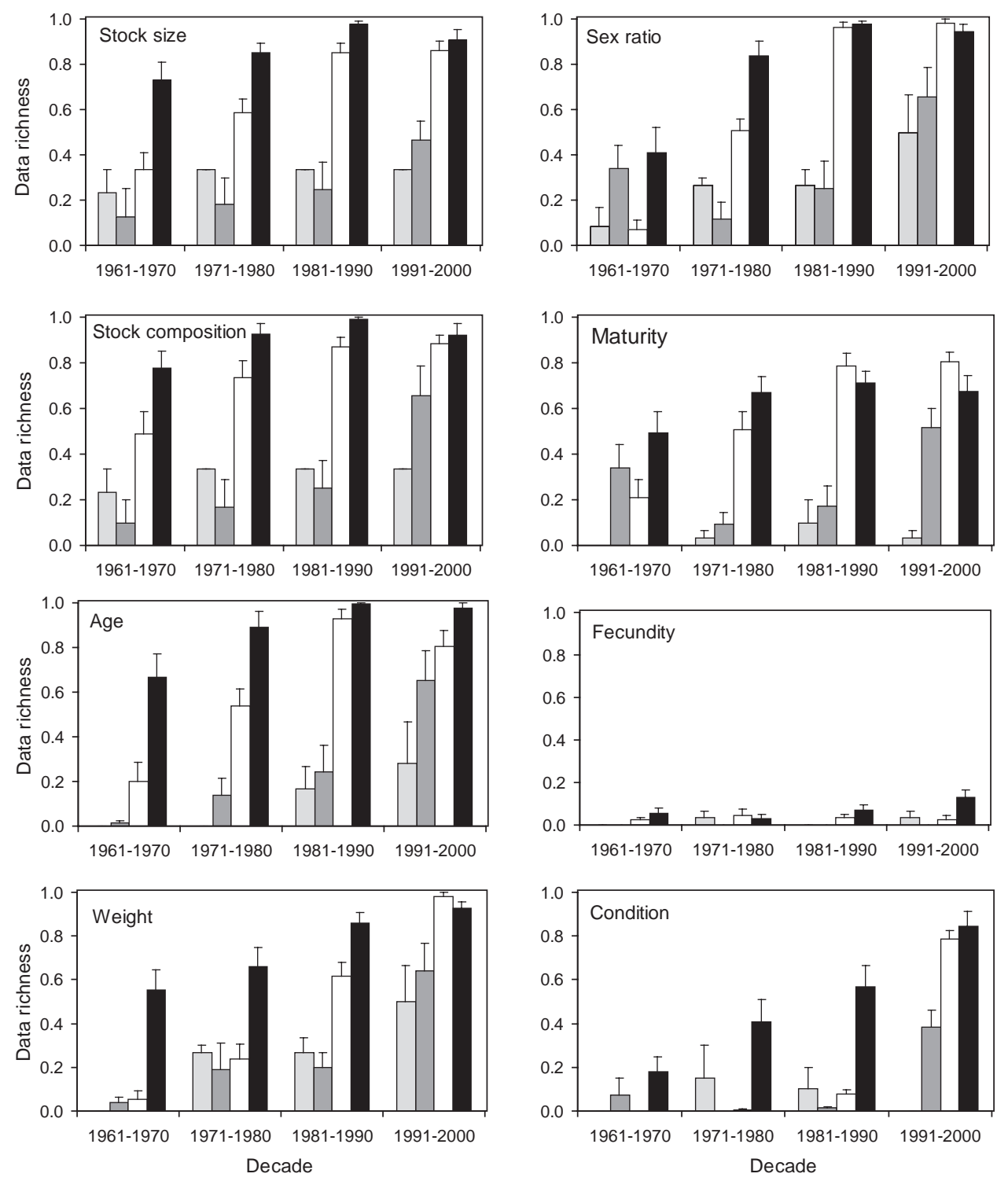

Fig. 6. Average data richness of different species groups within decades for the primary parameters related to reproductive potential. Standard error of each average is shown.

The stocks examined here include a range of traditionally-fished Northwest Atlantic groundfish stocks of variable size and economical importance (Pinhorn and Halliday, 1990). The differential acquisition of information for particular stocks has been influenced by domestic fishery management priorities prior to extended jurisdiction, international fishery management priorities under ICNAF and subsequently NAFO, the development of standardized fisheries-independent national and international surveys, and Canadian/USA transboundary resources (since 1984). Traditionally, the fishery for cod (Gadus morhua) is the largest groundfish fishery in the Northwest Atlantic, but the haddock (Melanogrammus aeglefinus) fishery is also economically important because of the relatively high unit price (Rivard and Maguire, 1993). The historical importance of the gadoid fishery is reflected in the long data series, which often dates back to the period before 1960 when stock sizes of cod, haddock and pollock (Pollachius 
TABLE 5. Additional information related to reproductive potential and stock-recruitment relationships given as number of publications per topic and time period.

\begin{tabular}{|c|c|c|c|c|c|c|c|}
\hline \multirow[b]{2}{*}{ Topic } & \multicolumn{6}{|c|}{ No. of Publications per Period } & \multirow[b]{2}{*}{ Total } \\
\hline & $\begin{array}{r}\leq \\
1960\end{array}$ & $\begin{array}{r}1961- \\
1970\end{array}$ & $\begin{array}{r}1971- \\
1980\end{array}$ & $\begin{array}{r}1981- \\
1990\end{array}$ & $\begin{array}{r}1991- \\
2000\end{array}$ & $\begin{array}{r}2001- \\
2002\end{array}$ & \\
\hline Spawning time & 3 & 7 & 41 & 27 & 45 & 13 & 136 \\
\hline Egg or larval viability & & & & 3 & 16 & 2 & 21 \\
\hline Potential or realized egg production & 1 & & & 3 & 13 & 1 & 18 \\
\hline Viable egg and larval production & & & 5 & 10 & 8 & 1 & 24 \\
\hline Critical life stages & & & & & & & 0 \\
\hline $\begin{array}{l}\text { Environmental influences on stock } \\
\text { reproductive potential }\end{array}$ & & & 1 & 4 & 15 & 2 & 22 \\
\hline Stock-recruitment relationships & & 1 & 1 & 6 & 25 & 5 & 38 \\
\hline Total & 4 & 8 & 48 & 53 & 122 & 24 & 259 \\
\hline
\end{tabular}

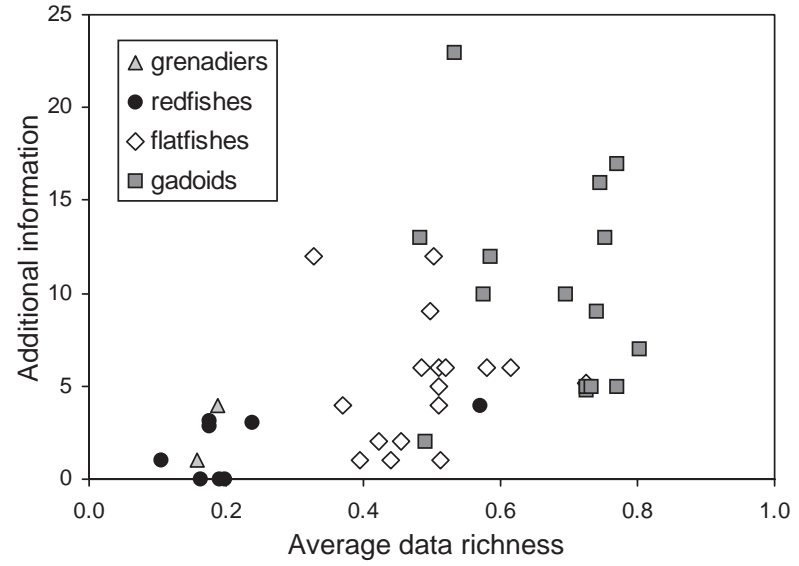

Fig. 7. Availability of additional information in relation to data richness score of stocks according to species group. The additional information refers to the number of publications related to stock reproductive potential and stock-recruitment relationships.

virens) were high. The traditionally lower magnitude of the flatfish fishery is reflected in the range of data series, which typically starts with intensified sampling programs for all species on surveys and key species in commercial landings accompanying the catch regulations implemented in the 1970s. An exceptionally long data series exists for Grand Bank American plaice (Hippoglossoides platessoides), which historically has comprised the largest flatfish fishery in the Northwest Atlantic. The magnitude of the redfish fishery traditionally has been relatively similar to flatfish, but as for the more marginal grenadier stocks, data richness among stocks was more variable. This at least partially relates to their distribution patterns with data quality in general being low for the deep-sea stocks and to the lack of species separation for some redfish "stocks". Adequate survey coverage of deep-sea stocks remains difficult, however European Union bottom trawl surveys on Flemish Cap and the Grand Bank in the 1980s and 1990s as well as the extension of Canadian surveys have substantially improved data quantity and quality in recent decades for stocks in these areas.

The declining gradient in average data richness from gadoids (0.68) to flatfishes (0.49), redfish (0.23) and grenadiers $(0.17)$ not only reflects the potential availability of data for estimating SRP indices among the examined species groups, but also reflects specific constraints in the available data. All gadoid and flatfish stocks reviewed had long to intermediary time series of stock size and age-length composition estimates derived mainly from analytical stock assessments, which generally provide a good basis for estimation of SRP indices. For grenadiers and redfish, the relatively short time series and low data quality constrains studies of SRP and stock-recruitment relationships at present except for the Gulf of Maine/ Georges Bank redfish stock. Low quality of weightat-age data for these two species groups reflects the limited stock coverage and also methodological problems in age determination of redfish (SaboridoRey, MS 1995). Both quantity and quality of ageing data were high for gadoids and flatfishes allowing for cohort analysis, whereas weight data to estimate stock 
biomass were more variable. Difficulties in obtaining accurate weights at sea in earlier decades resulted in lower data quantity and in intermediate quality scores, which mainly were due to weights derived from weight-length relationships. Time series incorporating natural variability in weight-at-age are very important when using SSB-based indices of SRP in stockrecruitment relationships as the weight parameter should reflect density dependent or environmentally induced changes in population fecundity. Fortunately, both data quantity and quality have substantially increased in recent years for many stocks as a result of the introduction of electronic scales at sea.

Maturity data were extensive for gadoid and flatfishes, whereas redfish maturity data generally were available from studies related to species differentiation early in the period and from intensified sampling in recent years. Maturity data for the two grenadier stocks were scarce and derived from single studies of species biology. Maturity data almost exclusively originated from surveys, but traditional visual staging of maturation without histological or other verification of data somewhat lowered the data quality scores. However, progress is being made in improving methodological aspects (e.g. Morgan and Hoenig, 1997; Saborido-Rey and Junquera, 1998; Burton, 1999; Wigley et al., 1999). For most gadoids and flatfish stocks, substantial temporal variation in maturity ogives has been reported, which reflect density-dependent growth changes related to fishery exploitation and environmental influences (e.g. Templeman et al., 1978; Bowering and Brodie, 1991; Morgan and Colbourne, 1999; O’Brien, 1999; Saborido-Rey and Junquera, 1999). Consequently, whenever possible, time series using annual or temporally discrete maturity ogives should replace knife-edge or constant maturity ogives. Case studies of Flemish Cap cod, Northeast Arctic cod and Baltic cod illustrate that integration of such data into SRP indices can significantly improve stock-recruitment relationships (Marshall et al., 2003).

It is an advantage that most of the maturity data available for the reviewed stock are sex specific. In most of the stocks, males mature at a smaller size and younger age than females, and often the lifespan of males is shorter than that of females. Differences in the length and age at $50 \%$ maturation are especially pronounced in the flatfish stocks (Bowering and Brodie, 1991; Burnett et al., 1992; O'Brien et al., 1993; Morgan and Colbourne, 1999; Walsh and Morgan, 1999), but also occur in many gadoid stocks
(Templeman et al., 1978; Beacham, 1983a,b,c; O'Brien et al., 1993, Trippel et al., 1997), grenadier stocks (Atkinson, 1995; Murua and Motos, 2000) and redfish stocks (Ni and Sandeman, 1984; Mayo et al., 1990). Earlier maturation in males than in females and potentially higher male mortality affect the composition of the spawning stock by sex and age (Jakobsen and Ajiad, 1999). Sexually dimorphic differences in growth and mortality have been considered in fisheries sampling and assessment models for flatfish stocks such as North Sea plaice (Pleuronectes platessa) and sole (Solea solea) (Bannister, 1977; ICES, MS 1982). Biological parameters and exploitation patterns differed between sexes in these stocks, but sexes were later combined within the assessment to reduce the coefficient of variation in virtual population analyses (ICES, MS 1982). However, sex-specific data are essential for the establishment of reliable SRP indices for sexually dimorphic species, because male maturation at a younger age is likely to result in a spawning stock dominated by male spawners especially at a high fishing mortality. Such a skewed sex ratio in the SSB would cause overestimation of the female spawner abundance affecting all non-sex specific SRP indices (Jakobsen and Ajiad, 1999). Although data are available to establish female spawner abundance for many of the 42 reviewed stocks, only a few stock assessments use FSSB as an indicator of stock reproductive potential (e.g. Avila et al., MS 1998; Saborido-Rey and Junquera, 1999).

Fecundity data were scarce throughout the entire period for all species groups. The low frequency and limited range of data severely constrains establishing fecundity time series based on empirical data. However, the quality of existing data generally is high and the data for some gadoid and flatfish stocks may be sufficient to consider variability in fecundity between periods or to establish relationships with environmental variables that might be used to hindcast fecundity. Fecundity is generally affected by food ration and condition, and these factors have been used in developing predictive relationships of fecundity based on prey availability, growth/condition and temperature (Buckley et al., 1991; Kjesbu et al., 1998; Kraus et al., 2000; Lambert et al., 2003). However, the availability of condition data generally is low and only a few stocks possess sufficient data to establish time series. Fulton's condition factor may be derived from length-weight data, but this condition factor is probably not the best indicator for fish species that primarily store their energy in the liver. For these 
species, the hepatosomatic index is a more accurate measure of condition (Marshall et al., 1999; Lambert et al., 2003). However, this indicator of condition is available for only a few of the examined stocks (Tyler and Dunn, 1976; Lambert and Dutil, 1997, 2000). For the redfish stocks reviewed, no fecundity data were available. Although redfish are viviparous, fecundity is determinate and development of eggs is lecitotrophic enabling fecundity estimates to be obtained using traditional methodologies for oviparous species.

Information on the influences of maternal characteristics on atresia, egg size and quality as well as egg and larval viability also is needed to fully consider female effects on reproductive potential (Trippel, 1999). Such aspects have been studied for few of the gadoid and flatfish stocks (Buckley et al., 1991; Chambers and Waiwood, 1996; Evans et al., 1996; Pepin et al., 1997; Trippel, 1998; Saborido-Rey et al., 2003). For grenadiers and redfish, which are difficult to rear in the laboratory, information hardly exists. Lower reproductive success of first-time spawners than for repeat spawners was evidenced for some stocks, owing to smaller body size of first-time spawners producing fewer and also smaller eggs that have lower quality and hatching success (Evans et al., 1996; Trippel, 1998; Wigley, 1999; Murawski et al., 2001). Male influences on egg fertilization and hatching success as well as egg and larval viability through differences in sperm quantity and quality have recently been studied (Trippel and Neilson, 1992; Rakitin et al., 1999; Trippel, 2003). However, there are only a handful of studies on the significance of male characteristics on stock reproductive potential at present. If variation in viable egg and larval production should be accounted for, data on specific characteristics of individuals composing the parental spawning stock are required (Trippel, 1999).

Compared to other additional information, data on spawning time and realized egg production were frequent and even existed in early decades (Lilly, 1987; Brander and Hurley, 1992, Berrien and Sibunka, 1999). These studies resulted from regular ichthyoplankton surveys, e.g., USA MARMAP plankton surveys and bilateral Russian-Canadian ichthyoplankton surveys. Such ichthyoplankton data may be useful in evaluating stock derived indices of egg production or in establishing alternative SRP indices (Marshall et al., 2003). The increase in the number of studies on environmental influences on SRP and stock-recruitment relationships in recent time clearly reflects the increasing awareness that stock overexploitation can lead to recruitment failure and that large-scale environmental factors also influence resource trends. However, no studies on critical life stages were reported and this identifies an area for future research, which is of vital importance in the understanding of stock-recruitment relationships.

Over the past four decades, data and results have become available for considering natural variability in biological parameters which should be useful in improving SSB, estimating FSSB or developing alternative indices. For the majority of stocks, the lack of fecundity data hampers establishment of PEP time series as well as more advanced indices of SRP that involve the influence of spawner characteristics on egg and larval viability. Data richness generally has improved in the most recent decade but there are also some exceptions. For some gadoid stocks, data richness declined slightly in the 1990s mainly due to limited sampling of depleted stocks reducing data quality, while the availability of age data deteriorated for flatfish for which production ageing has stopped for some stocks. The stock data richness indicates the potential for estimating SRP indices for different stocks, however knowledge about data formats (length, weight, and age) and relative importance of parameters are needed to evaluate data utility for specific stocks. The standardized tables used in the present study to record the amount, quality, format and sources of existing data as well as relevant SRP and stock-recruitment studies provide an overview of available information for each stock. The completed tables are published in the NAFO Scientific Council Studies, so that researchers can access the information for a given stock and locate the origin of the specific data and studies (Morgan et al., 2003).

International organizations such as ICES and NAFO are presently encouraging efforts to improve SRP indices for potential application in assessment and management. It is hoped that through these endeavours reliable biological reference points will be established, which are basic to a precautionary approach to fisheries management and sustainable fisheries (Rivard and Maguire, 1993; Trippel, 1999). Ignorance of variability in SRP adds uncertainty to stock-recruitment relationships, which affects the reliability of associated reference points. Yield-perrecruit derived reference points frequently applied for groundfish management in the Northwest Atlantic ignore variability in recruitment and the potential existence of stock-recruitment relationships. However, 
if stock size and recruitment are related, management options based on these reference points may not lead to sustainable fisheries (Mace and Sissenwine, 1993; Mace, 1994; Sinclair, 1999). In cases where information is insufficient to establish time series of SRP indices and complex reference points, identified information on reproductive characteristics of the stocks still may be useful to establish alternative reference points, e.g., multiple-limit-reference points (Caddy, 1999).

\section{Acknowledgements}

We thank Loretta O'Brien, Peter Wright and Hilario Murua for their assistance in designing the tables to record available data and information as well as the many colleagues, who have involved themselves in tabulating and updating the tables for specific stocks. We appreciate the constructive comments on the manuscript made by two anonymous referees.

\section{References}

ATKINSON, D. B. 1995. The biology and fishery of roundnose grenadier (Coryphaenoides rupestris Gunnerus, 1765) in the North West Atlantic. In: Deepwater fisheries of the North Atlantic oceanic slope. A. G. Hopper (ed.). Kluwer Academic Publishers, Dordrecht, The Netherlands, p. 51-111.

AVILA DE MELO, A., F. SABORIDO-REY, and R. ALPOIM, MS 1998. An assessment of redfish in NAFO Div. 3M including an approach to precautionary management based on spawning biomass and growth. NAFO SCR Doc., No. 53, Serial No. N3044, 51 p.

BANNISTER, R. C. A. 1977. North Sea plaice, In: Fish population dynamics. J. A. Gulland (ed.). John Wiley \& Sons, Ltd., London, England, p. 243-282.

BEACHAM, T. D. 1983a. Variability in size and age at sexual maturity of haddock (Melanogrammus aeglefinus) on the Scotian Shelf in the Northwest Atlantic Ocean. Can. Tech. Rep. Fish. Aquat. Sci., No. 1168, 37 p.

1983b. Variability in size or age at sexual maturity of white hake, pollock, longfin hake, and silver hake in the Canadian Maritimes area of the Northwest Atlantic Ocean. Can. Tech. Rep. Fish. Aquat. Sci., No. 1157, 47 p.

$1983 \mathrm{c}$. Variability in median size and age at sexual maturity of Atlantic cod, Gadus morhua, on the Scotian Shelf in the northwest Atlantic Ocean. Fish. Bull. U.S., 81: 303-321.

BEGG, G. A., and G. MARTEINSDOTTIR. 2002. Environmental and stock effects on spawning origins and recruitment of cod Gadus morhua. Mar. Ecol. Prog. Ser., 229: 263-277.

BERRIEN, P. and J. SIBUNKA. 1999. Distribution patterns of fish eggs in the Northeast Continental Shelf Ecosystem, 1977-1987. NOAA Tech. Rep. NMFS, No. 145: $310 \mathrm{p}$.
BEVERTON, R. J. H. and S. J. HOLT. 1957. On the dynamics of exploited fish populations. Fisheries Investment Series 2, Vol. 19, U. K. Ministry of Agriculture and Fisheries, London.

BOWERING, W. R. and W. B. BRODIE. 1991. Distribution of commercial flatfishes in the Newfoundland-Labrador region of the Canadian Northwest Atlantic and changes in certain biological parameters since exploitation. Neth. J. Sea Res., 27: 407-422.

BRANDER, K., and P. C. F. HURLEY. 1992. Distribution of early-stage Atlantic cod (Gadus morhua), haddock (Melanogrammus aeglefinus), and witch flounder (Glyptocephalus cynoglossus) eggs on the Scotian Shelf: a reappraisal of evidence on the coupling of cod spawning and plankton production. Can. J. Fish. Aquat. Sci., 49: 238-251.

BROMLEY, P. J., C. RAVIER, and P. R. WITTHAMES, 2000. The influence of feeding regime on sexual maturation, fecundity and atresia in first-time spawning turbot. J. Fish Biol., 56: 264-278.

BUCKLEY, L. J., A. S. SMIGIELSKI, T. A. HALAVIK, E. M. CALDARONE, B. R., BURNS, and G. C. LAURENCE. 1991. Winter flounder Pseudopleuronectes americanus reproductive success. II. Effects of spawning time and female size on size, composition and viability of eggs and larvae. Mar. Ecol. Prog. Ser. 74: 125-135.

BURNETT, J., M. R. ROSS, and S.H. CLARK. 1992. Several biological aspects of the witch flounder (Glyptocephalus cynoglossus L.) in the Gulf of Maine-Georges Bank region. J. Northw. Atl. Fish. Sci., 12: 15-25.

BURTON, M. P. 1999. Potential errors in measuring spawning stock biomass: Determining the effects of nonparticipatory adults for some Atlantic groundfish species. J. Northw. Atl. Fish. Sci., 25: 205-213.

CADDY, J. F. 1999. Deciding on precautionary management measures for a stock based on a suite of limit reference points (LRPs) as a basis for a multi-LRP harvest law. NAFO Sci. Coun. Studies, 32: 55-68.

CHAMBERS, R. C. and K. G. WAIWOOD. 1996. Maternal and seasonal differences in egg sizes and spawning characteristics of captive Atlantic cod, Gadus morhua. Can. J. Fish. Aquat. Sci., 53: 1986-2003.

EVANS, R. P., C. C. PARRISH, J. A. BROWN, and P. J. DAVIS, 1996. Biochemical composition of eggs from repeat and first-time spawning captive Atlantic halibut (Hippoglossus hippoglossus). Aquaculture, 139: 139149.

GUNDERSEN, A. C., K. H. NEDREAAS, O. S. KJESBU, and O. T. ALBERT. 2000. Fecundity and recruitment variability of Northeast Arctic Greenland halibut during 1980-1998, with emphasis on 1996-1998. J. Sea Res., 44: $45-54$.

HISLOP, J. F. G. 1988. The influence of maternal length and age on the size and weight of the eggs and the relative fecundity of the haddock, Melanogrammus aeglefinus, in British waters. J. Fish Biol., 32: 923-930.

ICES. MS 1982. Report of the North Sea Flatfish Working Group. ICES C.M. Doc., No. Assess: 3, 126 p.

JAKOBSEN, T., and A. AJIAD. 1999. Management implica- 
tions of sexual differences in maturation and spawning mortality of Northeast Arctic cod. J. Northw. Atl. Fish. Sci., 25: 125-131.

KJESBU, O. S., J. KLUNGSØYR, H. KRYVI, P. R. WHITTHAMES, and M. GREER WALKER. 1991. Fecundity, atresia, and egg size of captive Atlantic cod (Gadus morhua) in relation to proximate body composition. Can. J. Fish. Aquat. Sci., 48: 2333-2343.

KJESBU, O. S., P. R. WITTHAMES, P. SOLEMDAL, and M. GREER WALKER. 1998. Temporal variations in the fecundity of Arcto-Norwegian cod (Gadus morhua) in response to natural changes in food and temperature. J. Sea Res., 40: 303-321.

KÖSTER, F. W., H.-H. HINRICHSEN, D. SCHNACK, M. A. ST. JOHN, B. R. MACKENZIE, J. TOMKIEWICZ, C. MÖLlMANN, G. KRAUS, M. PLIKSHS, A. MARACHOUK, and E. ARO. 2003. Recruitment of Baltic cod and sprat stocks: Identification of critical life stages and incorporation of environmental variability and spatial heterogeneity into stock-recruitment relationships. Scientia Marina, (in press).

KÖSTER, F. W., H.-H. HINRICHSEN, M. A. ST. JOHN, D. SCHNACK, B. R. MACKENZIE, J. TOMKIEWICZ, and M. PLIKSHS. 2001. Developing Baltic cod recruitment models II: Incorporation of environmental variability and species interaction. Can. J. Fish. Aquat. Sci., 58: 1535-1557.

KRAUS, G., A. MULLER, K. TRELLA, and F. W. KÖSTER. 2000. Fecundity of Baltic cod: temporal and spatial variation. J. Fish Biol., 56: 1327-1341.

KRAUS, G., J. TOMKIEWICZ, and F. W. KÖSTER. 2002. Egg production of Baltic cod in relation to variable sex ratio, maturity and fecundity. Can. J. Fish. Aquat. Sci., 59: 1908-1920.

LAMBERT, Y., and J.-D. DUTIL. 1997. Can simple condition indices be used to monitor and quantify seasonal changes in the energy reserves of Atlantic cod (Gadus morhua)? Can. J. Fish. Aquat. Sci., 54 (Suppl. 1): 104-112.

2000 . Energetic consequences of reproduction in Atlantic cod (Gadus morhua) in relation to spawning level of somatic energy. Can. J. Fish. Aquat. Sci., 57: 815-825.

LAMBERT, Y., N. A. YARAGINA, G. KRAUS, T. MARSHALL, G. MARTINSDOTTIR, and P.J. WRIGHT. 2003. Using environmental and biological indices as proxies of egg and larval production of marine fish. J. Northw. Atl. Fish. Sci., 33: 115-159 (this volume).

LILLY, G. R. 1987. Synopsis of research related to recruitment of Atlantic cod (Gadus morhua L.) and Atlantic redfishes (Sebastes sp.) on Flemish Cap. NAFO Sci. Coun. Studies, 11: 109-122.

MACE, P. M. 1994. Relationships between common biological reference points used as thresholds and targets of fisheries management strategies. Can. J. Fish. Aquat. Sci., 51: $110-122$.

MACE, P. M. and M. P. SISSENWINE. 1993. How much spawning per recruit is enough? In: Risk evaluation and biological reference points for fisheries management. S. J. Smith, J. J. Hunt and D. Rivard (ed.). Can. Spec. Publ. Fish. Aquat. Sci., 120: 101-118.
MARSHALL, C. T., L. O'BRIEN, J. TOMKIEWICZ, G. MARTEINSDOTTIR, M. J. MORGAN, F. SABORIDOREY, F. W. KÖSTER, J. L. BLANCHARD, D. H. SECOR, G. KRAUS, P. J. WRIGHT, N. V. MUKHINA, and H. BJÖRNSSON. 2003. Developing alternative indices of reproductive potential for use in fisheries management: case studies for stocks spanning an information gradient. J. Northw. Atl. Fish. Sci., 33: 161-190 (this volume).

MARSHALL, C. T., N. A. YARAGINA, B. ÅDLANDSVIK, and A.V. DOLGOV. 2000. Reconstructing the stock/ recruit relationship for Northeast Arctic cod using a bioenergetic index of reproductive potential. Can. J. Fish. Aquat. Sci., 57: 2433-2442.

MARSHALL, C. T., N. A. YARAGINA, Y. LAMBERT, and O. S. KJESBU. 1999. Total lipid energy as a proxy for total egg production by fish stocks. Nature, 402: 288-290.

MARSHALL, C.T., O.S. KJESBU, N.A. YARAGINA, P. SOLEMDAL, and Ø. ULLTANG. 1998. Is spawner biomass a sensitive measure of the reproductive and recruitment potential of Northeast Arctic cod? Can. J. Fish. Aquat. Sci., 55: 1766-1783.

MARTEINSDOTTIR, G., and A. STEINARSSON. 1998. Maternal influence on the size and viability of Iceland cod Gadus morhua eggs and larvae. J. Fish Biol., 52: 1241-1258.

MARTEINSDOTTIR, G., and K. THORARINSSON. 1998. Improving the stock-recruitment relationship in Icelandic cod (Gadus morhua) by including age diversity of spawners. Can. J. Fish. Aquat. Sci., 55: 1372-1377.

MAYO, R. K., J. BURNETT, T. D. SMITH, and C. A. MUCHANT. 1990. Growth-maturation interactions of Acadian redfish (Sebastes fasciatus Storer) in the Gulf of Maine-Georges Bank region of the Northwest Atlantic. ICES J. Cons., 46: 287-305.

MORGAN, M. J. MS 2000. Estimating spawning stock biomass in $2 \mathrm{~J} 3 \mathrm{KL}$ cod using a cohort maturation model and variable sex ratio. Can. Stock Assess. Sec. Res. Doc., No. 2000/110, 17 p.

MORGAN, M. J., and E. B. COLBOURNE. 1999. Variation in maturity at age and size in three populations of American plaice. ICES J. Mar. Sci., 56: 673-688.

MORGAN, M. J., J. BURNETT, J. TOMKIEWICZ, and F. SABORIDO-REY. 2003. The availability of data for estimating reproductive potential for selected stocks in the north Atlantic. NAFO Sci. Coun. Studies, 37: 378 p.

MORGAN, M. J. and J. M. HOENIG. 1997. Estimating maturity-at-age from length stratified sampling. J. Northw. Atl. Fish. Sci., 21: 51-63.

MURAWSKI, S. A., P. J. RAGO, and E. A. TRIPPEL. 2001. Impacts of demographic variation in spawning characteristics on reference points for fishery management. ICES J. Mar. Sci. Symp., 58: 1002-1014.

MURUA, H., and L. MOTOS. 2000. Reproductive biology of roughhead grenadier (Macrourus berglax Lacèpéde, 1801) (Pisces, Macrouridae) in Northwest Atlantic waters. Sarsia, 85: 393-402

MYERS, R. A., and N. J. BARROWMAN. 1996. Is fish recruitment related to spawner abundance? Fish. Bull. 
U.S., 94: 707-724.

NI, I.-H. and E. J. SANDEMAN. 1984. Size at maturity for Northwest Atlantic redfishes (Sebastes). Can. J. Fish. Aquat. Sci., 41: 1753-1762.

O'BRIEN, L. 1999. Factors influencing the rate of sexual maturity and the effect on spawning stock for Georges Bank and Gulf of Maine Atlantic cod Gadus morhua stocks. J. Northw. Atl. Fish. Sci., 25: 179-203.

O'BRIEN, L., J. BURNETT, and R. K. MAYO, 1993. Maturation of nineteen species of finfish off the Northeast coast of the United States, 1985-1990. NOAA Tech. Rep. NMFS, No. 113: 66 p.

PEPIN, P., D. C., ORR, and J. T. ANDERSON. 1997. Time to hatch and larval size in relation to temperature and egg size in Atlantic cod (Gadus morhua). Can. J. Fish. Aquat. Sci., 54 (Suppl. 1): 2-10.

PINHORN, A. T., and R. G. HALLIDAY, 1990. Canadian versus international regulation of northwest Atlantic fisheries: Management practices, fishery yields, and resource trends, 1960-1986. N. Am. J. Fish. Manage., 10: $154-174$.

RAKITIN, A., M., M. FERGUSON, and E. A. TRIPPEL. 1999. Sperm competition and fertilization success in Atlantic cod (Gadus morhua): effect of sire size and condition factor on gamete quality. Can. J. Fish. Aquat. Sci., 56: 2315-2323.

RICKER, W. E. 1954. Stock and recruitment. J. Fish. Res. Board Can., 11: 559-623.

RIVARD, D. and J. J. MAGUIRE. 1993. Reference points for fisheries management: the eastern Canadian experience. In: Risk evaluation and biological reference points for fisheries management. S. J. Smith, J. J. Hunt and D. Rivard (ed.). Can. Spec. Publ. Fish. Aquat. Sci., 120: 31-57.

SABORIDO-REY, F. MS 1995. Age and growth of redfish in Flemish Cap (Div. 3M). NAFO SCR Doc., No. 31, Serial No. N2540, 16 p.

SABORIDO-REY, F., and S. JUNQUERA. 1998. Histological assessment of variations in sexual maturity of cod (Gadus morhua L.) at the Flemish Cap (North-west Atlantic). ICES J. Mar. Sci., 55: 515-521.

SABORIDO-REY, F., and S. JUNQUERA. 1999. Spawning biomass variation in Atlantic cod (Gadus morhua) in Flemish Cap in relation to changes in growth and maturation. J. Northw. Atl. Fish. Sci., 25: 83-90.

SABORIDO-REY, F., O. S. KJESBU, and A. THORSEN. 2003. Buoyancy of Atlantic cod larvae in relation to developmental stage and maternal influences. J. Plank. Res., 25: 291-307.

SCOTT, B., G. MARTEINSDOTTIR, and P. WRIGHT. 1999. Potential effects of maternal factors on spawning stockrecruitment relationships under varying fishing pressure. Can. J. Fish. Aquat. Sci., 56: 1882-1890.
SINCLAIR, A. 1999. Biological reference points relevant to a precautionary approach to fisheries management: an example for Southern Gulf of St. Lawrence cod. NAFO Sci. Coun. Studies, 32: 25-35.

TEMPLEMAN, W., V. M. HODDER, and R. WELLS. 1978. Sexual maturity and spawning in haddock, Melanogrammus aeglefinus, of the southern Grand Bank. ICNAF Res. Bull., 13: 53-65.

TRIPPEL, E. A. 1998. Egg size and viability and seasonal offspring production of young Atlantic cod. Trans. Am. Fish. Soc., 127: 339-359.

1999. Estimation of stock reproductive potential: history and challenges for Canadian Atlantic gadoid stock assessments. J. Northw. Atl. Fish. Sci., 25: $61-81$.

2003. Estimation of male reproductive success of marine fishes. J. Northw. Atl. Fish. Sci., 33: 81-113 (this volume).

TRIPPEL, E. A., and J. D. NEILSON. 1992. Fertility and sperm quality of virgin and repeat-spawning Atlantic cod (Gadus morhua) and associated hatching success. Can. J. Fish. Aquat. Sci., 49: 2118-2127.

TRIPPEL, E. A., M. J. MORGAN, A. FRÉCHET, C. ROLLET, A. SINCLAIR, C. ANNAND, D. BEANLANDS, and L. BROWN. 1997. Changes in age and length at sexual maturity of Northwest Atlantic cod, haddock and pollock stocks, 1972-1995. Can. Tech. Rep. Fish. Aquat. Sci., 2157: $120 \mathrm{p}$.

TYLER, A. V., and R. S. DUNN. 1976. Ration, growth, and measures of somatic and organ condition in relation to meal frequency in winter flounder, Pseudopleuronectes americanus, with hypotheses regarding population homeostasis. J. Fish. Res. Board Can., 33: 63-75.

ULLTANG, Ø. 1998. Where is fisheries science heading - how can fish stock assessment be improved? J. Northw. Atl. Fish. Sci., 23: 133-141.

VALLIN, L., and A. NISSLING. 2000. Maternal effects on egg size and egg buoyancy of Baltic cod, Gadus morhua. Implications for stock structure effects on recruitment. Fish. Res., 49: 21-37.

WALSH, S. J., and M. J. MORGAN. 1999. Variation in maturation of yellowtail flounder (Pleuronectes ferruginea) on the Grand Bank. J. Northw. Atl. Fish. Sci., 25: $133-140$.

WARE, D. M. 1980. Bioenergetics of stock and recruitment. Can. J. Fish. Aquat. Sci., 37: 1 012-1 024.

WIGLEY, S. E. 1999. Effects of first-time spawners on stockrecruitment relationships for two groundfish species. J. Northw. Atl. Fish. Sci., 25: 215-218.

WIGLEY, S. E., J. M. BURNETT, and P. J. RAGO, 1999. An evaluation of maturity estimates derived from two different sampling schemes: Are the observed changes fact or artifact. J. Northw. Atl. Fish. Sci., 25: 133-140. 



\section{Appendix 1. Parameter Specific Quality Criteria for Ranking Primary Parameters Applied to Estimate Reproductive Potential}

\section{Stock size}

3 Absolute stock size estimates from analytical models applying commercial catch and/or survey data with representative stock coverage.

2 Stock abundance indices from surveys with representative stock coverage, production models or analytical models utilizing landings or catch at age/length but with marginal diagnostics.

1 Landings data or survey abundance indices exist but with restricted coverage (area, season, years), sampling intensity or including mix of species/stocks.

\section{Stock composition}

3 Stock composition in numbers at age/length from analytical models including commercial catch statistics or from surveys with representative stock coverage.

2 Estimated or relative age/length composition from analytical models applying landings or catch at age/ length but with marginal diagnostics, production models or from survey abundance indices.

1 Age/length composition from landings, survey data with limited coverage or mix of species/stocks.

\section{Age}

3 Age determinations of fishes and age-length keys based on regular sampling of survey catches or commercial fisheries with representative stock coverage.

2 Age determinations of fishes from surveys or commercial fisheries available for a partial but at least a representative portion of the population or e.g. growth models based on empirical data exist allowing estimation of representative age-length keys.

1 Age determination of fishes and age-length keys from surveys are available, but considered inaccurate due to difficulties in e.g. age discrimination, low sample sizes or poor stock coverage.

\section{Sex ratio}

3 Data or estimates of sex ratios at age/length in the stock from surveys with representative coverage.

2 Survey based empirical data or estimates of sex ratio at age/length and representative of the stock.

1 Data or estimates of sex ratios at age/length based on surveys or catch data with e.g. limited, coverage of the stock or low sampling size.

\section{Maturity}

3 Sex-specific histological or histologically validated macroscopic maturity data at age/length from surveys with proper timing and sampling size.

2 Macroscopic maturity data at age/length from surveys with at least representative coverage, histological maturity data with limited sampling size or maturity indices from e.g. growth studies.

1 Data or estimates of maturity at age/length in the stock exist, but is subjected to error due to inadequate stock coverage, low sample size or methodological problems.

\section{Fecundity}

3 Estimates of individual fecundity at length/age or relative fecundity based on empirical data with confidence limits or other validation of applicability.

2 Estimates, indices or proxies of individual or relative fecundity at length/age, but in case of estimates with low precision or no validation.

1 Fecundity data, indices or proxies exist, but e.g. based on a very limited material or inadequate methodology. 


\section{Weight}

3 From surveys with proper stock coverage and a consistent sampling scheme.

2 Weight at age/length of fishes from survey or commercial catches with partial, but representative coverage of the stock, estimates obtained from length-weight relationships based on empirical data.

1 Weight at age/length in the stock or weight at age/length in the catch (measured or derived from length/ weight relationships), but not representative of the stock or subjected to other error.

\section{Condition}

3 Sex-specific seasonal data on Fulton's condition factor, hepatosomatic index or other condition parameters at age/length from surveys or commercial catches with representative sampling.

2 Data on Fulton's condition factor, hepatosomatic index or other condition parameters at age/length from surveys or commercial catches or indices/proxies exist that describe variation in female condition at an appropriate time of the year in relation to the reproductive cycle.

1 Condition at age/length or related parameters with e.g. improper timing of sampling in relation to the reproductive cycle, limited sample size or stock coverage. 


\section{Appendix 2. Definition of Topics Used to Categorize Publications Under Additional Information Related to Reproductive Potential and Stock-Recruitment Relationships}

\section{Spawning time}

Considers information on fish in spawning condition from trawl surveys and commercial vessels as well as egg abundance estimates from ichthyoplankton surveys.

\section{Egg viability}

Primarily experimental work on egg viability in relation to maternal length, age or nutritional condition through effects on egg size, density or buoyancy.

\section{Larval viability}

Experimental work relating parental effects of body size, age, nutritional condition to larval viability via differences in egg or sperm characteristics and fertilization success. Studies of parental behaviour such as differences in timing or location of spawning that influence survival through changes in ambient environmental conditions.

\section{Potential and realized egg production}

Studies that estimate egg production of a stock based upon data of primary parameters and indices or egg production estimates derived from ichthyoplankton surveys.

\section{Viable egg and larval production}

Studies that estimate the viable egg or larval production on the basis of data related to the parental stock from field and captive studies or production estimates derived from ichthyoplankton surveys.

\section{Critical life stages}

Considers experimental and field based work to reveal critical life stages in the recruitment process affecting the relationship between stock reproductive potential and recruitment.

\section{Environmental influences on stock-recruitment relationships}

Studies of conditions directly influencing the above processes and are important for the interpretation of stock-recruitment relations.

\section{Stock-recruitment relationships}

Studies that address the establishment of stock-recruitment relationships based on total egg production or indices of reproductive potential. 